\title{
The Significance of Everyday Life-An Ethnographic Study of Participation in Group-Based Patient Education
}

\author{
Tine Mechlenborg Kristiansen ${ }^{*}$, Rasmus Antoft ${ }^{2}$, Jette Primdahl3,4, Kim Hørslev Petersen ${ }^{3,4}$ \\ ${ }^{1}$ Department of Medicine and Health Technology, Aalborg University, Aalborg, Denmark \\ ${ }^{2}$ Department of Sociology and Social Work, Aalborg University, Aalborg, Denmark \\ ${ }^{3}$ Kong Chr. X's Hospital of Rheumatic Diseases, Graasten, Denmark \\ ${ }^{4}$ Department of Regional Health Research, University of Southern Denmark, Odense, Denmark

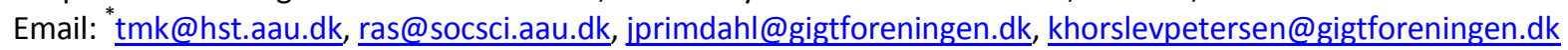

Received 22 December 2014; accepted 31 January 2015; published 3 February 2015

Copyright (C) 2015 by authors and Scientific Research Publishing Inc.

This work is licensed under the Creative Commons Attribution International License (CC BY).

http://creativecommons.org/licenses/by/4.0/

(c) (i) Open Access

\begin{abstract}
Drawing on a social phenomenological perspective in the sociology of everyday life, this ethnographic field study explores different ways in which women with rheumatoid arthritis perceive participation in a patient education programme as significant to their everyday lives. In particular, there are three ways in which this participation is perceived as significant to everyday life: as identity work, as an extension of "action space" in the practicalities of everyday life, and as a special community based on a common chronic condition. Furthermore, we uncover a difference in terms of what programme participation means to recently diagnosed participants, on one hand, and experienced participants, on the other hand, which is related to differences in their lived experiences of living with and managing chronic illness. This ethnographic study provides an important understanding of how these women create meaning inter-subjectively through social interaction but interpret this meaning individually based on their individual biographical experiences. The findings are relevant both to those who study the significance of patient education (both practitioners and researchers) and to those who are exploring how individuals make sense of living with chronic illness.
\end{abstract}

\section{Keywords}

Fieldwork, Everyday Life Sociology, Patient Education, Chronic Illness, Rheumatoid Arthritis

\section{Introduction}

Over the last century, both the prevalence of chronic illness and the life expectancies of people living with

Corresponding author.

How to cite this paper: Kristiansen, T. M., Antoft, R., Primdahl, J., \& Petersen, K. H. (2015). The Significance of Everyday Life-An Ethnographic Study of Participation in Group-Based Patient Education. Advances in Applied Sociology, 5, 81-93. 
chronic illness have increased in developed countries. For instance, it is estimated that one-third of the population in Denmark lives with one or more chronic illnesses and this percentage is expected to continue to grow in the coming years (Sundhedsstyrelsen (The National Board of Health), 2009). In addition, expenditures directly related to preventing and treating chronic illness account for $70 \%-80 \%$ of the total resources of the Danish health system (Sundhedsstyrelsen, 2009).

Health policy and health systems in developed countries have reacted to these developments by shifting their focus from treatment and care related to acute diseases to focusing on managing chronic illness over the long term (Gerhardt, 1990). Health promotion strategies are the cornerstone of this endeavour; in particular, groupbased patient education programmes have been offered to provide patients with tools to manage chronic illness.

In 2007, Denmark’s public health system was restructured and, as a consequence, health promotion became the common responsibility of both hospitals and local authorities. In addition, the government has financially supported the development of both disease-specific and generic patient education at the national, regional and local levels (Sundhedsstyrelsen, 2009).

Research on patient education has focused primarily on finding evidence of programme effectiveness in terms of improving the biomedical outcomes of symptoms, health-promoting behaviours, coping and health-related quality of life (Håkanson, Sahlberg-Blom, Ternestedt, \& Nyhlin, 2012; Sundhedsstyrelsen, 2009). Meanwhile, a growing number of qualitative studies have investigated the experiences of patients participating in patient education programmes. Most of these studies are evaluative, relating such experiences to the programme's overall goals, whether such goals are related to improving self-efficacy or empowerment (Barlow, Bancroft, \& Turner, 2005; Booker, Morris, \& Johnson, 2008; Dures et al., 2012; Monninkhof et al., 2004; Primdahl, Wagner, \& Hørslev-Petersen, 2011; Turner, Williams, \& Barlow, 2002).

Two ethnographic studies follow individuals as they participate in patient education programmes and after they have completed the programmes (Bülow, 2003; Grøn, 2005). Bülow and Hyden’s ethnographic study highlights not only how people collaborate to make sense of a contested illness, chronic fatigue illness (CFS), by sharing their experiences of the illness but also how this sharing helps ameliorate their sense of loss of self (Bülow, 2003). Grøn's anthropological study of three lifestyle-related chronic illnesses describes the everyday dilemmas involved in making changes to complex, ambiguous and vulnerable aspects of life (Grøn, 2005).

Consistent with Grøn's (2005) argument regarding the importance of understanding the complexity of everyday life, a central aim of this field study was to create new knowledge about what it means to people to participate in a local patient education programme by applying an everyday life perspective that focuses on participants' own narratives.

Following women who are participating in a local patient education programme and relying on a social phenomenological perspective, we focus on how the individuals studied create meaning inter-subjectively through social interaction but interpret that meaning individually depending on their individual biographies (BechJørgensen, 1994; Schutz, 2005).

The paper describes the following three ways in which participation is perceived as significant to everyday life: as identity work, as an extension of "action space" in the practicalities of everyday life, and as a special community based on a common chronic condition. Furthermore, we uncover a difference in terms of what programme participation means to recently diagnosed, on one hand, and experienced participants, on the other hand, which is related to differences in their lived experiences of living with and managing chronic illness.

\section{Theoretical and Analytical Framework: Looking through the Lens of the Sociology of Everyday Life}

We draw on an empirically driven phenomenological approach in the sociology of everyday life to conceptualise and achieve a nuanced understanding of the complexity of everyday life and the meaning of participating in patient education (Bech-Jørgensen, 1994) ${ }^{1}$.

This perspective views chronic illness as one among many life events causing more-or-less critical changes in everyday life and enables an investigation of how the individual, through social interactions, experiences and

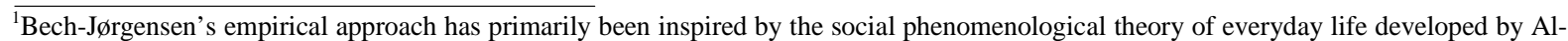
fred Schutz, but his approach has also been inspired by Agnes Heller's neo-Marxist approach to everyday life sociology and Johan Asplund's responsive sociology (Bech-Jørgensen, 1994). This approach was developed in empirical studies on young unemployed women living in suburban Denmark.
} 
handles chronic illness differently depending on their individual biographic situation² (Bech-Jørgensen, 1994; Schutz, 2005).

Everyday life is defined as "Life as it is lived, maintained, renewed and recreated every day..." (BechJørgensen, 1994; Bech-Jørgensen, 2002). It is studied as the interplay between everyday life as it is lived, the conditions of everyday life and how individuals manage these conditions (Bech-Jørgensen, 1994).

Bech-Jørgensen differentiates between activities and conditions on three structural levels: the unnoticed activities of everyday life, symbolic meaning universes and socially constructed institutions (Bech-Jørgensen, 1994). Her analysis concentrates on the conditions in her informants' everyday lives. In our analysis, we also prioritise the micro level perspective, following Bech-Jorgensen, although we recognize that structural determinants at the macro level affect the life conditions of our informants.

"The symbolic order of self-evidence" is defined as the fundamental condition of everyday life and is ordered by norms, rules, communication and objects—an order providing us with a fundamental ontological security. It is not a fixed order but an order that is constantly created and recreated by unperceived activities when individuals perceive meaningfulness in their everyday life activities and that is disrupted when individuals face life events that do not make sense to them, as may occur with the onset of chronic illness. Consequently, everyday life is a balancing act between self-evidence and chaos. Changes in everyday life can take on the character of more substantial disruptions, caused by, for example, unusual events that do not fit into our stock of knowledge ${ }^{4}$, more incremental and unnoticed displacements that occur every day, or by shifts caused by many internally connected displacements. Bech-Jørgensen describes these representative acts as the accumulation of unperceived activities through which individuals seek to assign meaning to everyday life through the use of symbols (Bech-Jørgensen, 1994).

Drawing on Alfred Schutz's concept of the world within reach and Johan Asplund's concept of social responsivity (Bech-Jørgensen, 1994), Bech-Jørgensen develops the concept of "simultaneous presence" to describe how subjectively experienced events can be transformed into common experiences, which occurs through social responsivity and an empathic responsivity. The concept of "simultaneous presence" refers both to being present together at the same time and to being together in the same physical and social space (presence). Bech-Jørgensen describes how new tactics to manage everyday life are created through "scopes of significances". Those "scopes of significances" are created on the border between self-evidence and chaos and through the creation of symbols and metaphors of thoughts, feelings, moods and experiences. These symbols are not only objects but also acts, events, qualities or relations and are not only based on common meanings but are also inherently capable of creating individual interpretations and changes that are tested responsively through replies and further responses (Bech-Jørgensen, 1994).

\section{Methods}

An ethnographic field study was conducted between April and December 2012 to explore how participants perceived their participation in a patient education programme as significant to their everyday lives. The study was part of Ph.D. research conducted by the first author, who also performed the fieldwork.

\subsection{The Empirical Case}

The programme was established as a collaboration between the rheumatic departments at two hospitals and two local community health care centres in Denmark ${ }^{5}$. The programme was developed in cooperation between an

\footnotetext{
${ }^{2}$ Alfred Schultz developed the concept of an individual "biographical situation" and argues that the individual is always faced with a particular biographical situation in his/her everyday life, which means that he/she belongs to a particular physical and sociocultural environment in which he/she occupies a special position. This positioning is undertaken in both a physical space and in the social system by taking a special status and social role in and related to moral and ideological issues. The concept contains all the factors-both in the past and in the present - that have affected the individual and his/her special biographical situation (Schutz, 2005).

${ }^{3}$ The concept of "the symbolic meaning universes" is parallel to Berger and Luckmann's (1967) concept of symbolic universes defined as all social objectivations referring to realities other than that of everyday life. However, whereas Berger and Luckmann have built their concept on the assumptions of Schutz's natural attitude as "the paramount reality" compared to other meaning provinces, for example, dreams, play or arts, Bech-Jørgensen uses the concept of "the symbolic meaning universes” to stress the difference related to the status ascribed to one’s natural attitude (Bech-Jørgensen, 1994: pp. 158, 168-170).

${ }^{4}$ The "stock of knowledge" is defined as the common-sense knowledge that we develop from the everyday life world in which we are engaged. Bech-Jørgensen has adapted this concept from Alfred Schutz (Bech-Jørgensen, 1994).

${ }^{5}$ The project was financed by grants from the Danish Ministry of Health and Health Promotion as part of increased interventions for patients with chronic diseases (Sundhedsstyrelsen (The National Board of Health), 2010.
} 
interdisciplinary group of health care professionals representing these organisations and five user representatives (hereafter: "lay experts") (Kristiansen, Primdahl, Antoft, \& Hørslev-Petersen, 2015, in press) ${ }^{6}$. The programme targeted people with rheumatoid arthritis (RA) and was carried out in two geographically distinct local settings.

The health pedagogical basis of the programme was situated within a constructionist perspective on learning with attention directed at specific problems of everyday life (Møller Ølgaard et al., 2013). The stated purpose of the programme was to support people in building up emotional, physiological and social resources through co-constructing knowledge and sharing experiences. Another aim was to help each participant create a network of support.

Both the health professionals from the hospitals and the local community health care centres and the lay experts with RA — who had participated in developing the programme-were co-workers in the programme. The health professionals included rheumatologists, nurses, physiotherapists, occupational therapists, a social worker, a dietician and a psychologist. The role of the health professionals was to provide disease-specific knowledge about medical treatment, symptoms, activity and rest, in addition to knowledge about the psychological and social aspects of life with RA. The lay experts were meant to facilitate the exchange of experiences among the participants and to contribute with their own experiences. The goal was for the participants to build up their knowledge about RA and its practical management in everyday life, rather than passively receiving information (Møller Ølgaard et al., 2013).

The programme consisted of five three-hour thematic meetings with a 14-day break between each meeting to allow participants to reflect on what they learned and to practise new ideas or strategies in their everyday lives (Møller Ølgaard et al., 2013).

\subsection{Participants}

The fieldwork followed programme participants in each local setting. The formal requirements for participation included that participants live in one of the two communities taking part in the delivery of the programme, that participants had been diagnosed with RA and consulted with either of the two hospitals that was participating in the programme or with a private rheumatologist in one of the two communities. The two courses had 12 and 10 participants, respectively. All the participants were women, who varied in age, educational background, relation to the labour market, disease duration and severity of illness.

To understand how participants ascribed meaning to their participation, we found it important both to follow some of the participants in their everyday lives and to follow them over time to explore whether their perception of the significance of their participation changed or was reformulated (Wadel, 1991). Six women were asked to allow the fieldworker to visit them in their home surroundings. These key informants were recruited by employing purposeful sampling criteria with the aim of including a range of informants across the characteristics of age, civil status, educational background, work situation and disease duration.

\subsection{Conducting Participant Observation at the Programme and in the Home Surroundings}

The fieldworker conducted participant observation during the thematic meetings of the programme. She presented herself as a Ph.D. student positioned outside the educational programme who was interested in exploring the participants' experiences. The fieldworker was aware that this positioning might be difficult because she had been part of the development process and was well acquainted with the co-workers in the programme (Kristiansen et al., 2015). The degree of participation and observation varied between the formal parts of the programme, which consisted of the health professionals' information and the exchange of experiences-during which the fieldworker took on an observing role because she could not share the experiences of a life lived with RA-and the informal parts of the programme during breaks, during which the fieldworker played a more active part in the informal interaction among the participants.

Conducting fieldwork at home we combined individual interviews with participant observation. The fieldwork in the home surroundings was initiated by a first visit and interview while the programme was running. The interviews focused on the women's illness narratives, their everyday lives and their motivation for joining the programme. Furthermore, the interviews were used as formal entry into the field and the first negotiation of the fieldwork during which the fieldworker and the women discussed the scope of the fieldwork and the everyday life activities that the fieldworker would be welcome to follow and join.

Three to six months after the programme had finished, the fieldworker visited the women in their home envi-

\footnotetext{
${ }^{6}$ In Denmark, local community health care centres are primarily responsible for preventive healthcare services. In particular, they offer a range of patient education programmes for people with chronic diseases.
} 
ronment one or two more times and participated in routine matters of everyday life, such as the daily tasks of cooking, baking, etc., and in events to which the informants ascribed significant meaning, such as leisure activities, work and socialising with family and friends. Finally, individual interviews were conducted in December 2012. These interviews explored what it had meant to the women to participate in the programme, followed up on questions or reflections related to the individual women and symbolised a formal withdrawal from the field.

In addition, two semi-structured focus group interviews with all the participants were conducted two weeks after completion of the programme to obtain the overall impression of how the participants had experienced participation and what it had meant to them in their everyday lives. Eleven of the 22 women participated in the focus groups.

All the interviews were audio-taped and transcribed verbatim, and field notes were also taken to document non-taped conversations and events before, after, and sometimes during interviews. Descriptive field notes were taken during participation in the programme and immediately after field visits in the home surroundings. Throughout the fieldwork, a reflective diary was maintained for the fieldworker to self-evaluate her role and to reflect on questions, enigmas and emergent analytical ideas (Emerson, Fretz, \& Shaw, 1995).

\subsection{Data Analysis}

The fieldworker performed the analysis. The results were regularly discussed with the co-authors. Initially, the transcripts were read several times and themes and subthemes were identified inductively and coded with references to each of the six key informants to keep track of their personal narratives over time (Ritchie \& Lewis, 2003) and to explore their lived experiences as they reflected on and expressed them. The coded data were condensed by formulating the initially identified statements into shorter messages, attempting to remain close to the expressions used by the informants. Next, the condensed data were coded across the informants to include the field notes and the focus group interviews more actively for the purpose of obtaining a more general basis for the empirical findings and conclusions. Finally, the analytical framework and central concepts from Bech-Jørgensen's phenomenological approach within the sociology of everyday life was adapted (Bech-Jørgensen, 1994; Bech-Jørgensen, 2002) to provide a more in-depth analysis and interpretation of the three themes that emerged from the initial inductive analysis and to strengthen its analytical generalisability (Coffey \& Atkinson, 1996).

\section{Findings}

We now present the three modes of significance of participation in everyday life and illustrate the differences between the recently diagnosed and the experienced women that are most clearly related to the first two modes of significance.

\subsection{Identity Work through Simultaneous Presence at the Programme}

In the following section, we analyse how participation in the programme had a variety of significance to the sense of identity of the individual women.

\subsubsection{Re-Orientation and Creating Identity}

For all the recently diagnosed women, coming to terms with RA and finding hope for the future had been a major motivational factor in joining the programme. For most of the recently diagnosed women, the onset of RA was a fundamental disruption in their lives, and they related how they had attempted to protect themselves and their sense of self against this disruption in the self-evidence and taken-for-grantedness of everyday life. For example, these women had struggled to continue working, doing housework, looking after their grandchildren, etc., to confirm to themselves and to those around them that they remained the same person. For all the women, maintaining their former identity was challenging because they could not maintain all the activities and social interactions upon which their identity was based.

While participating in the programme, all the women were attempting to find and create meaningfulness related to their life with RA. During the sessions, a social responsivity (Bech-Jørgensen, 1994) developed in which the women felt mutually recognised and understood. They associated these mutual feelings of empathy and sympathy with the fact that they were all surviving through the same circumstances and had the same chronic condition, which made it easier to understand one another and to stand in each other's shoes. Once experienced as their own individual problems, the feelings, sensations and worries resulting from the onset of RA were transformed into common experiences through their "simultaneous presence" (Bech-Jørgensen, 1994) in and at the programme. 
The empathy that was created not only led to a feeling of a mutual understanding and a safe atmosphere but also extended the self-understanding of most of the recently diagnosed women through individual interpretations of the feelings expressed by the others. Encountering the experienced women who had lived with RA for many years was particularly important because these women offered a way to re-orient their identities in a parallel process of accepting and integrating chronic illness into their everyday lives while striving to maintain normality. Through a continuous dialectic process of responding to each other's contributions, the experienced women described how they had struggled to re-orient themselves and to accept the new conditions of their lives, how they had overcome that struggle and how they had settled into a new sense of self. Simultaneously, some of the experienced women remained in the work force and did not have any obvious deformities that could draw attention to their RA. In this way, they also symbolised normality and ignited hope in the recently diagnosed women that they would be able to continue a normal life.

Anna was one of the recently diagnosed women who had experienced how meeting other women had helped her re-orient her identity. She had been diagnosed with RA for approximately one year following a divorce: thus, she had experienced RA as a further disruption to her life. When the fieldworker first met Anna, her RA was aggressive and caused severe symptoms. She was concerned about the future and worried about both the prospects of getting better and whether she would be able to maintain her job and take care of her family. Anna's major concern was learning both to accept RA and to integrate it into her life. When the fieldworker visited Anna after the programme, her sense of mental fatigue and feeling of being overwhelmed had vanished. She had managed to maintain her work and was able to take care of her family.

Anna defined learning to live with her condition as an on-going learning process in which she had taken the first important steps and had moved closer to accepting RA after meeting others with the condition. This process is exemplified in the following interview extract:

Anna: The meetings that we had, I think it was nice that we were that different. I mean that some had had rheumatoid arthritis for many years and some of us were just diagnosed. We could talk together and look to those who had had it for a long time. They could tell us how they had managed and what we could do.

Interviewer: So you think this big difference was a good thing?

Anna: Yes, I do. Because, you know, when you are new, you stand there and think, oh gosh, where has the good life gone, right! Then, it is nice to hear from some of the others that they found the good life or are close to it, right? And oh yes, this stuff doesn't need to be such a big thing in your life.

In this way, meeting the other women-particularly the experienced women-had helped Anna move towards an acceptance of her chronic condition.

\subsubsection{Non-Identification}

Anna's story resembles the stories of most of the recently diagnosed women, but a few of them did not engage themselves with this identity work and did not take an active role in the social interaction.

Lisa was one of these women. When she entered the programme she had been diagnosed with RA for only approximately 6 months but had suffered from severe symptoms for a year before she was diagnosed. Lisa had experienced the onset of RA as a fundamental disruption in her life. Due to severe pain, fatigue and functional limitations, she was no longer able to work. During the nine months of fieldwork, her physicians tried different medications, but none effectively reduced her symptoms. Visiting Lisa, it was obvious that RA challenged her normal role in her family, in which she used to be the caregiver and housekeeper. For example, she was not able to do the laundry, she could not do the cleaning and cooking and sometimes she needed help undressing before going to bed at night, in addition to needing help getting out of bed in the morning. RA had changed her relationship to her own body, from which she felt estranged. She feared becoming disabled and helpless.

In the programme, Lisa never involved herself in the common discussions and mutual exchange of experiences, and she frequently seemed to be mentally absent and absorbed in her own thoughts.

Visiting Lisa was different than visiting the other key informants. Due to her functional limitations, she did not perform many routine matters of everyday life in her household or join in activities outside her home. The field visits therefore took place as conversations in the living room. The following field note excerpt illustrates Lisa's experiences of participation and their lack of significance to her everyday life:

\footnotetext{
"Lisa says that she did not have the energy to participate actively at the meetings and that she was not able
} 
to concentrate both because of her pain and because of her worries and her thoughts that were completely overwhelming her... She thinks it was important to meet somebody who had lived with RA much longer than she had, but she also experienced it as frightening to hear what might await her in the future... Lisa says that she doesn't think it is a good idea to join a programme right after getting a diagnosis because it takes all one's focus" "it's better to wait till you have settled a little".

Viewed through Bech-Jørgensen’s analytical framework Lisa’s reaction-in both her private life and during the programme meetings - can be interpreted as a bodily and mental withdrawal to protect herself from the disruptions to her everyday life caused by RA.

Although unique, Lisa's story also resembles the everyday life conditions of a few other recently diagnosed women who-due to this overriding feeling of uncertainty and chaos—-felt they were not able to concentrate and be mentally present at the meetings.

\subsubsection{Confirming Identity}

Most of the experienced women did not think that meeting others with RA had changed how they perceived themselves. Reflecting on the initial insecurity, fear and emotional frustrations expressed by those recently diagnosed, they confirmed for themselves both that they had handled RA in the right way and that they now lived a good life. Regardless of how RA had changed their self-perception, they all had developed new routines and habits and new symbolic tactics for managing RA that made sense for them. They had created meaningfulness in their lives.

Sarah had lived with RA for more than 30 years and was the woman who was the most disabled by RA; she had visible deformities in her hands and feet. She had retired early due to the impairments caused by RA. Sarah is a widow and manages her household and garden tasks on her own. It is a central concern for her to remain autonomous and independent of both her family and local community services. She uses many aids in everyday life and has created her own daily rhythm, taking the time she needs and planning many breaks during the day. The field note excerpt below shows how RA has gradually become a self-evident part of Sarah's everyday life and self-identity.

"Sarah tells me that she has learned to live with the RA and has become used to it... it has become an integrated part of her life. She says that life with RA has become normal and that joining the programme hasn't changed how she perceives herself".

Simultaneously, Sarah's identity as a self-managing and autonomous person is confirmed when meeting the recently diagnosed women, whom she describes as "maybe a little too self-pitying and passive in managing this new condition". At one of the sessions at which an announced theme was the use of aids, Sarah brought a bag with a selection of some of her daily aids. She was urged to show the other women her aids and while circulating the aids around the table, she explained how they help her "to live an independent life, where I am able to handle most things on my own”.

\subsection{Creating Action Space through the Practicalities of Everyday Life}

In the following section, the analysis focuses on how the significance of participation in the programme varied greatly to the women, in terms of how they handled RA practically in everyday life.

\subsubsection{Creating Individual Action Space through Others' Significant Experiences}

Most of the newly diagnosed women felt that the encounters with the more experienced women and the lay experts gave them input and tools to help manage the practicalities of everyday life. They were relieved to hear that those who had lived with RA for several years had experienced the same challenges and to learn how they had managed their limitations and found practical solutions. Through a range of adaptations, for example, using aids and learning to plan and prioritise activities, the more experienced women and lay experts managed to live almost normal everyday lives. This information gave the recently diagnosed women both new practical knowledge and the motivation to try out new ways to handle everyday life challenges. They began to create new tactics to manage everyday life by creating "scopes of significances" (Bech-Jørgensen, 1994), which developed through the common exchange of experiences. These new tactics were created in common but were interpreted individually depending on the women's everyday lives, their individual life stories and the concrete practical challenges they faced with RA. The interview extract and the field note transcript below not only demonstrate 
how Anna created new tactics to manage everyday life but also illustrate how new modes of managing RA are characterised by feelings of ambivalence.

Anna: You know, using the right knife, using a rucksack when going shopping and getting some proper shoes to prevent my feet from hurting so much, and things like that. In this way, I think that, on a practical level, I have learned a lot. I have also gradually learned, but still only in my family, to say that I have to take a break, just to relax a little.

Later, Anna talked more about these practical tactics in everyday life and revealed the ambivalences connected to these changes.

"Anna told me how she has gradually learned to tell her family what she can manage and what she cannot manage. She says that sometimes she goes into her bedroom to rest while she is with her family because she needs rest. She tells me that she hired a removal company to arrange her moving house and that she bought fabric-made curtains, which she would never have done before... Anna says that it's still quite difficult to say no to extra tasks at work or to refuse to help her father or her grown children and grandchildren and reflects that she must learn that it is okay to say no".

For most of the newly diagnosed women, information from the health professionals about medical treatment, how to handle symptoms, how to take care of their bodies and the legal aspects related to aids and the labour market were all experienced as important pieces of knowledge that might support them in their everyday lives. Simultaneously, they thought that information was delivered from some of the health professionals as patronising or simply lacking an understanding or special knowledge of both the disease-specific situation of people living with RA and the related emotional reactions of the newly diagnosed.

Reflecting on her experiences of encounters with health professionals, Anna talked about their implicit and frequently unspoken expectations of the participants in terms of doing their "chronic homework" (Mattingly, Meinert, \& Grøn, 2011). This concept refers to health professionals' claims related to adapting to the chronic condition and initiating behaviour changes that—from a health professional's perspective-would be necessary to cope with RA in a responsible and self-managing manner. For example, Anna should lose weight, exercise, ask for help, adopt a positive attitude towards RA and accept her limitations in everyday life. These prescriptions caused her to suffer from a guilty conscience because she felt unable to fulfil these expectations. As illustrated below, she felt that the health information should be targeted to her more as an individual and should be offered when she was motivated to make changes in her life:

Anna: I think it's different when you are ready to accept information-for example, about nutrition. Because in a way, I know, but I am not able to do something about it right now. Very quickly, it becomes information that I don't take in and where I think yes, just hit me on my head, right?

\subsubsection{When the Significant Experiences of Others Are of No Use}

The experienced women did not think that they had obtained any new knowledge from the health professionals. Instead, they believed that the health professionals' information targeted the newly diagnosed. They also regarded the significant experiences of the other women as having little relevance to their lives. They had adapted to their disruptions and limitations, created new routines and habits, and maintained other routines, depending on their individual biographical situations (Schutz, 2005), for example their underlying normative discourse on how the right adaption to chronic illness should be, their social, personal and financial resources, the severity of their RA and their own self-perception.

Marion, who had lived with RA for nine years, hoped to gain new knowledge from the health professionals about medical treatment, exercise and the connection between RA and food. During the focus group interview, she and two other women, who had also lived with RA for many years, reflected on their different expectations.

Káte: Well, I do not think that the knowledge that we want actually exists because, eh, we know many things already.

Kathrin: Yes, because we have had it for SO many years.

Káte: Yes, for so many years, and because we are members of the Danish Rheumatism Association and read their news, we talk to our rheumatologists about the latest knowledge, we read about medicine and 
side effects and we have tried out many different medicines, so to be honest, is there really much that's new? Marion: Something new could turn up, we hope for some news, don't we?

\subsection{A Community Based on the Common Condition}

We have described the community that developed between the women in the programme as an intimate and trustful community created through "simultaneous presence” (Bech-Jørgensen, 1994). Through constant replies and responses, the participating women had developed a special responsivity and empathy based on being in the same situation. The fieldworker's own observations and reflections during the programme support the impression of a special community to which neither the fieldworker nor the health professionals could fully belong. The field note extract below is from a meeting in one of the local groups at which two health professionals discussed psychological reactions to RA.

"The health professional shows a slide with an elephant and a text about the willingness to be 'more than just your illness'. Julie starts crying and says that, up till now, she 'thought just like you', that it's important to recognise your illness", but since she became "disabled", she has suffered from an identity crisis. She also says that everybody asks, "Julie, how are you?” and that she just wants to be normal and not be seen as ill... I have just thought about picking up my rucksack, to get some tissues, but Anna already has some tissues and hands them to me. I take a tissue and hand it over to Julie. Marie, sitting on the other side of Julie, puts a comforting hand on Julie's shoulder. Alice says, "Just cry, it’s ok, it’s good that you can express it". The lay expert offers to have a talk with Julie later”.

\subsubsection{Differing Needs for a Wider Social Network Based on the Common Condition}

Although almost everyone emphasised the special feeling of community, not everyone wanted to continue meeting on a regular basis after the programme had concluded. Approximately two-thirds of the women continued meeting on a regular basis ${ }^{7}$. It was obvious that the various women had different motivations for joining the network and different expectations regarding the community they hoped to join after leaving the programme and returning to their everyday lives. These differences might partly be explained by the duration of their disease; however, it also seems to be closely associated with their personal resources and social networks.

A majority of the women wanted to meet around social and physical activities relating to their common condition. They wanted to begin engaging in exercise—such as Nordic walking—and to support one another in establishing new habits. They were convinced that this community would be better to join than formal associations, such as sports groups or fitness clubs, because no special consideration would have to be made when they were not able to participate on an equal footing, for example, because they could not walk as fast or as long as the others. In this community of equals, they assumed that their limitations would be understood.

Sarah enjoyed the informal and safe atmosphere at the meetings; she felt more comfortable with others who were in the same situation. The field note extract below illustrates the hopes that Sarah attaches to the new social network.

"Sarah says that she thinks the people in the group are able to understand her physical limitations. It makes her relax and prevents her from pushing herself too hard. She says that she would like to join common activities and events, smiles and says that she would really like to start Nordic walking in the group and that she already has Nordic walking poles”.

A few of the recently diagnosed women (such as Anna) viewed the network more like a self-help group, in which they could discuss things that were hard to accept and hard to manage in everyday life; in particular, they could discuss things that were hard to discuss with their families because they were concerned regarding both the changes in their roles and their intimate relationships in the family.

After the first three meetings of the new network, Anna was disappointed that the group did not become a self-help group. Anna reflected on the balance between the recently diagnosed and the experienced women and described it as unequal because those recently diagnosed, such as herself, gained from the experiences of the other women but did not give much back. Two of the experienced women had decided to join another group

${ }^{7}$ The meetings were organised differently in the two local settings. In one setting, the women had to establish the network on their own, whereas in the other, the meetings were organized by the lay experts. Because meeting organisation is not the focus of this analysis, it will not be described further. 
with more experienced members established from a previous cohort of the same programme, and Anna believed that their decision was due to this imbalance.

The interview extract below is from the final visit and interview at Anna’s house:

Anna: I had hoped that this group, that we could support one another. I mean, I already have a normal "get together group” with my friends, right? And my family. I don't need that.

Interviewer: Okay, you needed something more related to your all having RA?

Anna: YES. And I really missed that. Because when you visit privately, you become a guest and you have to socialise and make small talk. I think it's that part about living alone that challenges me. Both that I'm supposed to do it all on my own, no matter what, and that it's the same mind-set. That's why I want this network because you tend to close in on yourself and use the same pictures and the same way to think, right? And you need to discuss some of these things and realise, oh, you might see it all from another perspective.

As discussed above, Anna had experienced a disruption in life due to a recent divorce, and the onset of RA had intensified her need to find new meaning in life in her new life condition - as a single woman with an unpredictable, chronic condition.

\subsubsection{Leaving the Community}

For a variety of reasons, some of the recently diagnosed women and some of the experienced women chose not to join the network. Some of the women had a pre-existing strong network and did not want to extend themselves further. Others, in some cases the same women, did not want to focus on their chronic condition.

Marion participated at the first meeting of the network and decided not to continue. Marion defined herself as a person who was flexible and able to manage changing circumstances. She used those personal characteristics to explain how she had learned to accept RA as an integrated part of her life without letting it take control of her life. Her RA had fluctuated, leading her to endure two flare-ups that had affected her self-perception negatively and had left her feeling more vulnerable. She says that accepting RA is clearly easier in good times-when she feels more in control of the illness and able to continue her daily routines - than in bad times, during which the new routines of everyday life are threatened. During the programme and the fieldwork, Marion experienced a good time with symptoms, which she can control through medicine. The field note extract below is from a visit at Marion's house after the programme finished.

"I ask Marion whether she has decided about the network and Marion says that, yes, she has decided not to join. She says that she doesn't want to be reminded more of her RA than she already is, and talks about medications, syringes and consultations in hospital that give her regular reminders. Marion says that she "doesn't need that".

Reflecting on the mutual empathy and sympathy among the women during the programme, Marion did not consider it to be essentially different from the responsivity that she felt from her family or potentially could have with people with other chronic conditions. Marion had previously established new routines in everyday life and had created a new sense of identity and meaningfulness. She had integrated RA into her life without letting it take too much control and did not want to be reminded too much about the consequences of living with RA.

\section{Concluding Discussion}

In this paper, we have drawn on a phenomenological perspective in the sociology of everyday life to grasp the significance of participation in patient education (Bech-Jørgensen, 1994). Drawing on more general concepts related to everyday life highlights its complexity and shows that chronic illness is one problem among many that can cause disruptions, breaks or slips in our lives. These events might exacerbate the experience of chaos and the need for social support.

This article's main argument is that group-based patient education might provide special support to those recently diagnosed with a chronic illness during this transformation period of their everyday lives. The article demonstrates three modes of significance ascribed to participation, which were primarily experienced by the recently diagnosed women. Through the women's "simultaneous presence" (Bech-Jørgensen, 1994) in the programme and the continuous exchanges of experiences-particularly between the recently diagnosed and the experienced women (and the lay experts)—-those women's individual experiences are transformed into common 
experiences, which provides the basis for creating a new self-evidence related to life with RA and the basis for integrating RA into their everyday lives and identities. Bülow (2003), from a narrative perspective, have reported similar findings, emphasising the creation of meaning as a social interaction process in studying participation at a Swedish patient school.

Furthermore, this article highlights how new "scopes of significances" (Bech-Jørgensen, 2002) are also created through the exchange of experiences, thoughts, moods and feelings related to living with an unpredictable chronic condition. By means of these commonly created "scopes of significances," new tactics for managing the practicalities of everyday life are created by individual interpretations and adaptations to individual biographical situations (Schutz, 2005). This process of learning through others has also been described in Håkanson et al.'s (2012) study of a Swedish group-based educational programme for people with irritable bowel syndrome. They relate "learning about oneself through others" to both the exchange of experiences among the participants and participants' own reflections on this exchange; they describe both learning related to a changed self-image and learning related to useful everyday life strategies.

Supporting the anthropological analysis of Grøn (2005) we have further highlighted that changing the practicalities of everyday life is related to feelings of ambivalence and vulnerability. Changing how one manages everyday life with chronic illness is not an incremental act, but rather is a highly social act, affecting social relations and social roles and changing social interactions. For example at the job, refusing taking overtime or asking for special considerations due to the causes of the chronic illness. Or changing interactions and role patterns in the family, transforming the former role of being the caregiver to a new role of being a person who might need care and support.

Finally, the article shows how programme participants create a special community based on being in the same situation. Håkanson et al. (2012) have described the same special community that is based on being among others with similar illness experiences and define it as a safe community in which participants feel mutually understood and supported and that provides them with comfort and strength.

The studies of Bülow and Hýden (2004); Bülow (2003) and Håkanson et al. (2012) share our perspective on the role of the socialisation processes at a programme in which meaning is socially constructed. However, in contrast to our study, those authors do not follow the participants to their everyday life settings to investigate how commonly created meanings are individually interpreted and transformed, depending on an individual's biographical situation (Schutz, 2005).

Another main argument is that not everyone gains from joining group-based patient education programmes. We demonstrated this lack of experienced significance by analysing the cases of the experienced women and of a few recently diagnosed women. The experienced women had established a new sense of self and had established new routines in everyday life, incorporating and qualified by their illness. Thereby, joining the programme did not affect how they perceived themselves and managed their RA. However, for most, participation was experienced as a nice way to meet "equals". This analysis also reveals the experiences of a few of the recently diagnosed women, who had experienced a fundamental life disruption and overriding feelings of uncertainty and chaos and who, therefore, were unable to concentrate and be mentally present at the meetings. Viewed through Bech-Jørgensen's analytical framework, this passive participation can be interpreted as bodily and mental withdrawal to protect themselves from RA-related disruptions to everyday life. This complexity of life circumstances is important to recognise and address if patient education is to be perceived as meaningful.

In contrast to our findings, none of the above-mentioned Scandinavian studies have focused on differences between the recently diagnosed and the experienced women in how they ascribe meaning to their participation. Furthermore, there have been no other international studies that focus on this significant difference.

Considering the special community at the programme meetings, our analysis documents that the intimate community is not automatically transformed from one context to another because the participants do not all have the same expectations of - and need for-an on-going community based on their chronic illness. There is quite a difference between wanting to meet on an informal basis around common activities and the need to establish a self-help group at which participants are expected to discuss far more private and vulnerable affairs. We have not found other empirical studies investigating efforts to create a lasting social network after participation in patient education programmes. Further research on this aspect of these programmes is needed.

We have focused on the role of social interactions among the women because the analyses showed that the role of the health professionals was not experienced as significant either because it was experienced as being tailored towards the recently diagnosed or because it was not experienced as directed at the participants' indi- 
vidual needs or life situations. Adapting the concept of “chronic homework” (Mattingly et al., 2011), we demonstrated how health professionals' implicit and frequently unspoken expectations about being positive, accepting the chronic condition, and initiating behaviour changes to become a responsible and self-managing person might lead to feelings of shame and guilt. Accordingly, meeting health professionals can be an ambivalent experience. This subject thus opens a discussion of ethical dilemmas in patient education in terms of who has the right to determine what is right for an individual joining the programme.

Our study was able to describe only the experiences of women: no men took part in the two programmes that the fieldworker followed. Following Bech-Jørgensen, the "symbolic order of self-evidence" (Bech-Jørgensen, 1994) is primarily structured in a gender-specific fashion; social norms, social roles, and role expectations are social constructions and are gender-specific. Related to our study, we would expect gender-specific differences in the experience of how RA affects everyday life. In addition, there are possible differences in how men and women might ascribe meaning (or lack of meaning) to their participation. These potential gender-based differences impose a natural limitation to our study because we can only refer to our findings for women.

\section{References}

Barlow, J. H., Bancroft, G. V., \& Turner, A. P. (2005). Self-Management Training for People with Chronic Disease: A Shared Learning Experience. Journal of Health Psychology, 10, 863-873. http://dx.doi.org/10.1177/1359105305057320

Bech-Jørgensen, B. (1994). Når Hver dag Bliver Hverdag (When Every Day Becomes the Everyday). Aalborg: Aalborg Universitet.

Bech-Jørgensen, B. (2002). Forskning og Hverdagsliv (Research and Everyday Life) (Vol. 1). Forskningsgruppen Arbejdsog Levemiljøer (Research Group on Work and Living Environments) (pp. 3-48). Aalborg: Aalborg Universitet.

Berger, P. L., \& Luckmann, T. (1967). The Social Construction of Reality. A Treatise in the Sociology of Knowledge. New York: Anchor.

Booker, S., Morris, M., \& Johnson, A. (2008). Empowered to Change: Evidence from a Qualitative Exploration of a UserInformed Psycho-Educational Programme for People with Type 1 Diabetes. Chronic Illness, 4, 41-53.

http://dx.doi.org/10.1177/1742395307086695

Bülow, P. (2003). Sharing Experiences of Contested Illness by Storytelling. Discource and Society, 15, 33-53.

Bülow, P., \& Hýden, C. (2004). Patient School as a Way of Creating Meaning in a Contested Illness; the Case of CFS. Health: An Interdisciplinary Journal for the Social Study of Health, Illness and Medicine, 7, 227-249.

Coffey, A., \& Atkinson, P. (1996). Making Sense of Qualitative Data, Complementary Research Strategies. London, Thousand Oaks, CA and New Delhi: Sage Publications.

Dures, E., Kitchen, K., Almeida, C., Ambler, N., Cliss, C., Hammond, A., Knops, B., Morris, M., Swinkels, A., \& Hewlett, S. (2012). “They Didn’t Tell Us, They Made Us Work It out Ourselves”: Patient Perspectives of a Cognitive-Behavioral Program for Rheumatoid Arthritis Fatigue. Arthrtis Care and Research, 64, 494-501.

Emerson, R. M., Fretz, R. I., \& Shaw, L. L. (1995). Writing Ethnographic Fieldnotes. Chicago, IL: The University of Chicago Press. http://dx.doi.org/10.7208/chicago/9780226206851.001.0001

Gerhardt, U. (1990). Qualitative Research on Chronic Illness: The Issue and the Story. Social Science \& Medicine, 30, 11491159. http://dx.doi.org/10.1016/0277-9536(90)90255-Q

Grøn, L. (2005). Winds of Change, Bodies of Persistence: Health Promotion and Lifestyle Change in Institutional and Everyday Contexts. The University of Aarhus: Aarhus.

Håkanson, C., Sahlberg-Blom, E., Ternestedt, B. M., \& Nyhlin, H. (2012). Learning about Oneself through Others: Experiences of a Group-Based Patient Education Programme about Irritable Bowel Syndrome. Scandinavian Journal of Caring Sciences, 26, 738-746. http://dx.doi.org/10.1111/j.1471-6712.2012.00990.x

Kristiansen, T. M., Primdahl, J., Antoft, R., \& Hørslev-Petersen, K. (2015). The Two Faces of User Involvement: Everyday Life and Local Context. Tidsskrift for Forskning i Sygdom og Samfund (Journal of Research in Illness and Society).

Mattingly, C., Grøn, L., \& Meinert, L. (2011). Chronic Homework in Emerging Borderlands of Healthcare. Culture, Medicine, and Psychiatry, 35, 347-375. http://dx.doi.org/10.1007/s11013-011-9225-z

Møller Ølgaard, U., Andersen, A. B., Bagger, B. M., Frøhlich, K., Dencker Hansen, B., Johansen, C., Schulz, S., \& Hørslev-Petersen, K. (2013). Evalueringsrapport. Forpligtende fællesskaber mellem sygehuse, kommuner og brugere skaber sammenhæng og nye løsninger indenfor patientuddannelse (Evaluation Report. Committed Communities among Hospitals, Municipalities and Users Create Coherence and New Solutions within Patient Education). In Gråsten Aabenraa Kommune, Vejle Kommune, Vejle Sygehus, Kong Chr. X'Gigthospital, Gråsten (Community of Aabenraa, Community of Vejle, Vejle Hospital and King Chr. X (pp. 1-71). Gråsten: Hospital for Rheumatic Diseases. 
Monninkhof, E., van der Aa, M., van der Valk, P., van der Palen, J., Zielhuis, G., Koning, K., \& Pieterse, M. (2004). A Qualitative Evaluation of a Comprehensive Self-Management Programme for COPD Patients: Effectiveness from the Patients' Perspective. Patient Education and Counseling, 55, 177-184. http://dx.doi.org/10.1016/j.pec.2003.09.001

Primdahl, J., Wagner, L., \& Hørslev-Petersen, K. (2011). Being an Outpatient with Rheumatoid Arthritis-A Focus Group Study on Patient' Self-Efficacy and Experiences from Participation in a Short Course and One of Three Different Outpatient Settings. Scandinavian Journal of Caring Sciences, 25, 394-403. http://dx.doi.org/10.1111/j.1471-6712.2010.00854.x

Ritchie, J., \& Lewis, J. (2003). Qualitative Research Practice-A Guide for Social Science Students and Researchers. London, Thousand Oaks, CA: Sage Publications Ltd.

Schutz, A. (2005). Hverdagslivets Sociologi-En Tekstsamling (The Sociology of Everyday Life-A Collection of Texts). København (Copenhagen): Hans Reitzels Forlag.

Sundhedsstyrelsen Monitorering og Medicinsk Teknologivurdering (National Board of Health Monitoring and Medical Techonology Assessment) (2009). Patientuddannelse-En medicinsk teknologivurdering (Patient Education-A Health Technology Assessment). http://sundhedsstyrelsen.dk/Publ/Publ2009/MTV/Patientuddannelse/Patientuddannelse.pdf

Turner, A., Williams, B., \& Barlow, J. (2002). The Impact of an Arthritis Self-Management Programme on Psychosocial Wellbeing. Health Education, 102, 95-105. http://dx.doi.org/10.1108/09654280210425985

Wadel, C. (1991). Feltarbeid i egen kultur-En innføring i kvalitativt orienteret samfundsforskning (Fieldwork in Your Own Culture-An Introduction to Qualitative Social Science Research). Flekkefjord: Hegland Trykkeri A/S. 
Scientific Research Publishing (SCIRP) is one of the largest Open Access journal publishers. It is currently publishing more than 200 open access, online, peer-reviewed journals covering a wide range of academic disciplines. SCIRP serves the worldwide academic communities and contributes to the progress and application of science with its publication.

Other selected journals from SCIRP are listed as below. Submit your manuscript to us via either submit@scirp.org or Online Submission Portal.
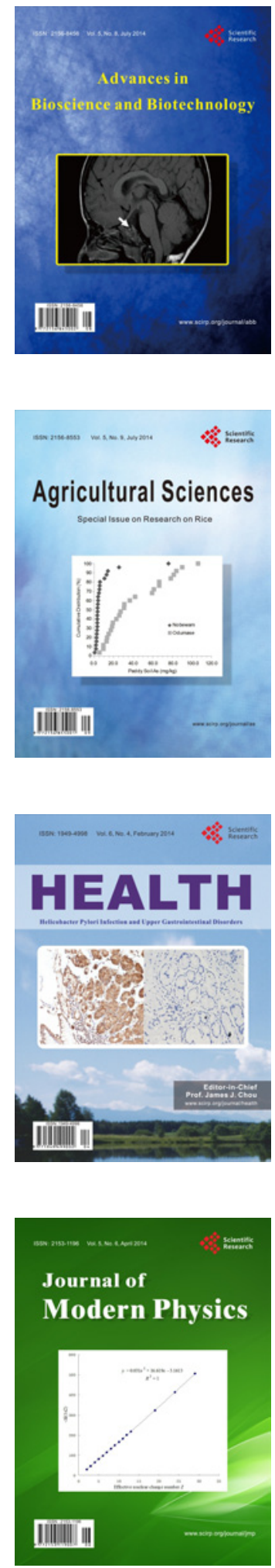
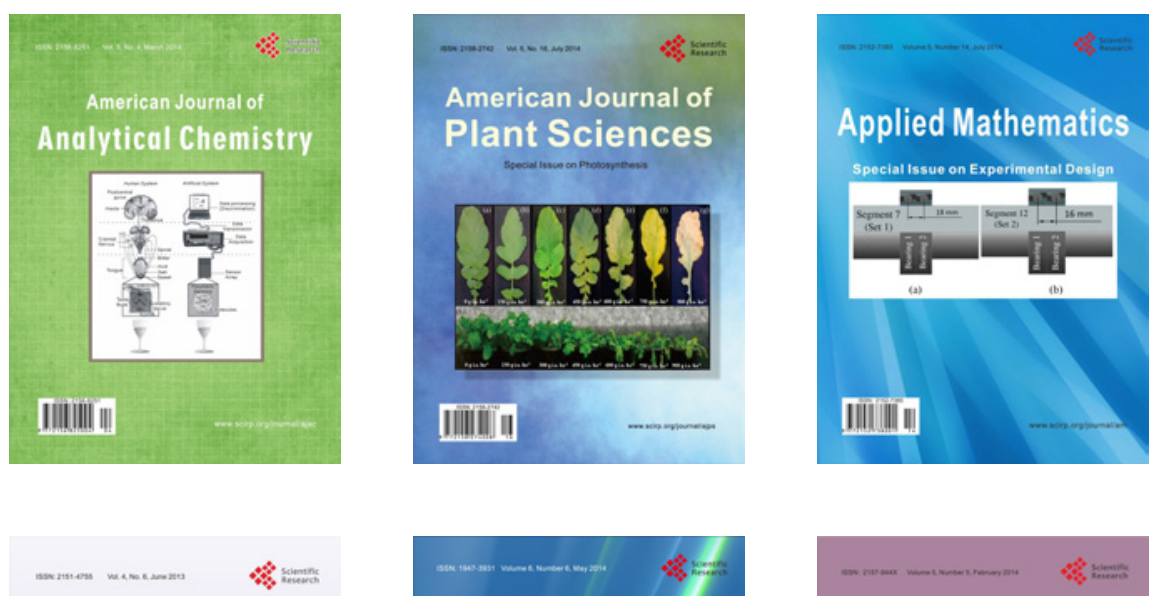

Creative Education
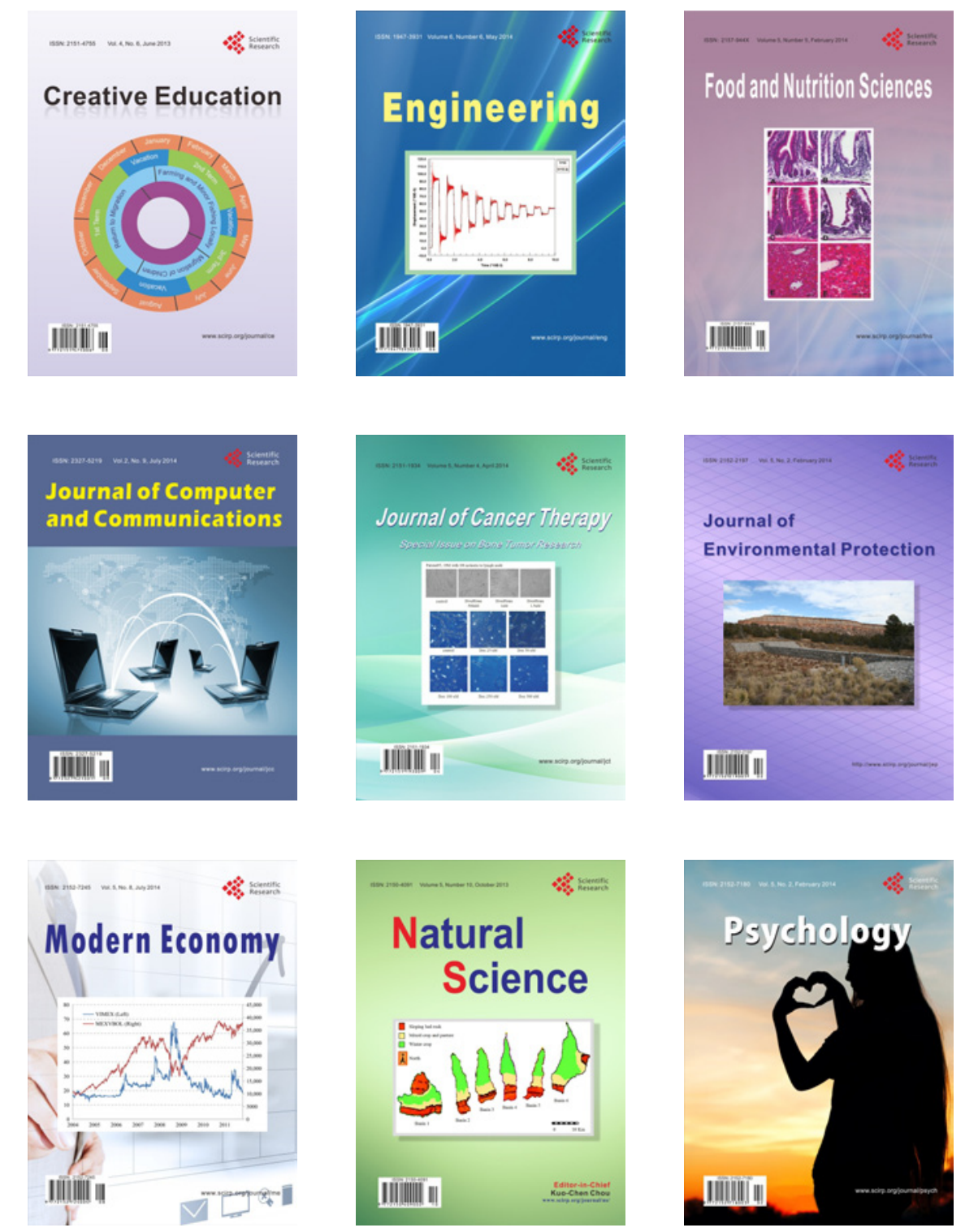